\title{
Private Entrepreneurs Challenging the Socialist
} System?

The Election Fraud in the People's Congress of Liaoning Province and Its Implications

Anthony H. F. Li

\section{CpenEdition}

\section{Journals}

Electronic version

URL: http://journals.openedition.org/chinaperspectives/7233

DOI: $10.4000 /$ chinaperspectives.7233

ISSN: 1996-4617

\section{Publisher}

Centre d'étude français sur la Chine contemporaine

\section{Printed version}

Date of publication: 1 March 2017

Number of pages: 97-101

ISSN: 2070-3449

Electronic reference

Anthony H. F. Li, «Private Entrepreneurs Challenging the Socialist System? », China Perspectives [Online], 2017/1 | 2017, Online since 01 March 2017, connection on 15 September 2020. URL : http:// journals.openedition.org/chinaperspectives/7233 


\title{
Cefe News Analysis
}

\section{Private Entrepreneurs Challenging}

\section{the Socialist System?}

\author{
The Election Fraud in the People's Congress of Liaoning Province and Its Implications
}

\author{
ANTHONY H. F. LI
}

\section{Introduction}

$\mathrm{O}$ n 13 September 2016, the Standing Committee of the National People's Congress (NPCSC) held an extraordinary meeting and announced a decision unprecedented in the history of People's Republic of China (PRC). It disqualified 45 out of 102 delegates to the National People's Congress (NPC) elected from the Liaoning's People's Congress (LPC) for massive election fraud in the election of these delegates back in January 2013. The disqualification also resulted in removing 38 of the 62 members of the LPC Standing Committee, making the body short of the quorum required to convene meetings. Of the 523 (out of a total of 619) members of the LPC who were implicated in the vote-buying scandal, 453 resigned and one was sacked from their positions in the LPC. (1) The NPCSC later organised a "preparatory panel" to arrange a re-election of new members for the LPC. Due to the unprecedented nature of the non-functional LPC, the NPCSC was required to handle the situation through an "innovative arrangement" (chuangzhi xing anpai 创制性安排). (2) The president of the NPCSC, Zhang Dejiang, framed the incident as "touching the bottom line of the socialist system with Chinese characteristics," (3) and the Chinese Communist Party (CCP) also pinpointed in a circular that the incident was a "serious violation of party discipline" and "serious destruction of the electoral system of the People's Congress." (4) Some media highlighted the news by labelling it a "case of paramount importance" (tian zi yi hao an 天字一号案). Of the 45 disqualified NPC delegates, 40 are private industrial entrepreneurs, four are executives of state-owned enterprises, and one is a public servant. ${ }^{(5)}$ The majority of disqualified members with business backgrounds also points to the noticeable presence of business tycoons in the NPC. This paper intends to describe Liaoning's election fraud and its consequences in detail, put it in the context of Xi Jinping's Administration, and discuss its implications for the party-business relationship and elections in China.

\section{The People's Congress system under Xi Jinping}

Like the National Party Congress of the CCP, the People's Congress system (the PC system) in the PRC is underscored by the principle of "democratic centralism." As the full assembly of the PC is only in session for several weeks in a year, the standing committee holds de facto power to execute legislative duties the rest of the time. However, the existence of the CCP alongside the PC system has long formed an informal power locus that decisively influences the operation of the PC system through the Party group (dangzu 党组) in the standing committee. (6) Members of the Party group are subordinate to directives and orders from their superiors in the CCP. The implication of this party-state fusion is that the PC system is heavily dictated by a few Party members in the standing committees at the various PC levels. (7)

With regards to the election of $P C$ delegates, members of the PC below the county level are elected by direct election. The PCs above the county level have their members elected from the PCs at the immediate-lower level, constituting the element of indirect election in the PC system. It is, however, no secret that the CCP attempts to control the electoral process through managing the list of nominated candidates and to drive off independent candidates who are not sponsored by the CCP. ${ }^{(8)}$ However, such control has become less absolute since the introduction of the "candidate-more-than-post" system (cha'e xuanju, 差额选举) in 1982, which introduced a slight degree of uncertainty to the overall electoral process.

1. "Liaoning Legislature removes over 400 lawmakers," Global Times, 19 September 2016, http://www.globaltimes.cn/content/1006938.shtml (accessed on 13 January 2017).

2. "Liaoning hu xuan an zhi sheng renda yu bacheng daibiao huo ci huo mian" (Over $80 \%$ of delegates resigned or removed after Liaoning's election fraud), Caixin, 13 September 2016, http://china.caixin.com/2016-09-13/100988251.html (accessed on 17 November 2016).

3. Cao Yin, "45 NPC deputies unseated for fraud," China Daily, 14 September 2016, http://www.chinadaily.com.cn/china/2016-09/14/content_26789503.htm (accessed on 20 December 2016).

4. "Zhongyang chachu Liaoning la piao hui xuan an" (Central authority handled the case of Liaoning election fraud), Caixin, 5 September 2016, http://china.caixin.com/2016-09-05/100985437.html (accessed on 23 December 2016).

5. Choi Chi-yuk, "Behind the NPC vote-buying scandal: How Beijing went on the warpath after its preferred candidates lost," SCMP, 26 October 2016, http://www.scmp.com/news/china/policiespolitics/article/2024604/behind-npc-vote-buying-scandal-how-beijing-went-warpath (accessed on 20 December 2016).

6. Murray S. Tanner, The Politics of Lawmaking in Post-Mao China, New York, Clarendon Press, 1999.

7. He Zunzhi, Zuowei yi zhong zhengfu xingshi de zhongguo renda zhidu (China's People's Congress System as a Government Form), Shanghai, Shanghai Renmin Chubanshe, 2013; Ming Xia, The People's Congresses and Governance in China, London, Routledge, 2007.

8. "China's local elections: Democracy 'with Chinese characteristics'," Hong Kong Free Press, 16 November 2016, https://www.hongkongfp.com/2016/11/16/chinas-local-elections-democracychinese-characteristics/ (accessed on 20 December 2016). 
Among many other functions, the PC serves to represent Chinese nationals from various geographical regions as well as an array of sectors, including peasants, workers, women, ethnic minorities, intelligentsia, and Returned Overseas Chinese. At the national level, the eight "democratic parties," the People's Liberation Army, and representatives from Hong Kong, Macau, and "Taiwan" are also included. Regional representation is manifested in the ways delegates are elected and PC meetings are organised. ${ }^{(9)}$ Also, the higher-level PC is responsible for allotting and approving the representation quotas for the above-mentioned sectors in the PC of the immediate-lower level, as stipulated in the Election Law. At the national level, Party leaders have at least two ways to ensure that the candidates they sponsor become NPC delegates. First, the NPCSC can centrally assign (zhongyang fenpei 中 央分配) candidates to the provincial groups of delegates in the name of making the NPC more comprehensively representative. (10) Second, Qin Qianhong points out that the majority of delegates to the NPC are usually pre-selected by the CCP's Organisation Department and United Front Department at both the national and provincial levels, after consultation with the standing committee of the provincial PC in question. The two departments will use their own measures to ensure that CCP-endorsed candidates are elected. ${ }^{(11)}$ The representation quotas and the list of pre-selected candidates are supposed to serve as a dictate for the provincial PC's standing committee when it administers the election of its delegates to the NPC.

Nonetheless, the PC system is not an outright top-down administrative system where Party leaders can assert full control. The NPC does not actually lead (lingdao 领导) the provincial ones and tell what to do on all issues. There is indeed a limited degree of autonomy for provincial PCs, especially after the significant reform of the PC system introduced immediately after the Cultural Revolution. ${ }^{(12)}$ Given the practical autonomy of provincial PCs, conflicts might arise between them and the NPC. Informal mechanisms such as guanxi (personal connection) between PC delegates at the two levels and the CCP's rules that govern the behaviour of Party group members in their respective standing committees become important complements to the operation and coordination of the overall PC system. ${ }^{(13)}$

Indeed, election fraud is not uncommon in the PC system. ${ }^{(14)}$ Although only a few seats are left for competition under the "candidate-more-thanpost" system, many vote-buying practices take place in this part of the electoral process. ${ }^{(15)}$ The results of the Liaoning election in January 2013 particularly infuriated the Party leaders under Xi linping's leadership because some of the representation quotas reserved for peasants and grassroots representatives set by the NPCSC were not observed, and 11 candidates for NPC delegates shortlisted by Party leaders were not elected, but were substituted by candidates who allegedly bribed their way into office. (16) Given the lack of observance of the Centre's orders and the sheer scale of the election fraud in the LPC, the Party Centre carried out investigations on the possible involvement of the then chairman of the Standing Committee of the LPC, Wang Min 王珉, and other leading cadres in the vote-buying scandal.

The lack of observance of the Centre's orders can be understood in the changing political context under the Xi Administration. Since Xi Jinping has become Party leader, a number of "flies" and "tigers" within the Party have been prosecuted on the grounds of graft and violations of party discipline. The fall of senior Party cadres such as Zhou Yongkang and Ling Jihua is inevitably re-making the power dynamic among the various factions within the Party. In the shadow of the anti-graft campaign and intense intra-party factional struggle, Chen Ling and Barry Naughton argue that what is ex- pected from local cadres has departed from previous Party norms, making the criteria for cadres' promotion less clear and cadres' careers more unpredictable. ${ }^{(12)}$ The failure of Liaoning's provincial cadres to observe the Centre's orders in the election of delegates to the NPC, and their reluctance to remedy the situation in accordance with the central authorities' instructions at a later time, suggest that the CCP's informal mechanisms to control local cadres might not be as effective under the Xi Administration, and that it has offered greater leeway for unapproved business tycoons to advance their interests up to the national level of the PC system.

\section{Re-making Party discipline in Liaoning Province}

To investigate the extent of corruption in Liaoning Province, the Central Inspection Group (Zhongyang xunshi zu 中央巡视组) was dispatched to the province in 2014. The subsequent investigation report criticised provincial Party leaders for failing to apprehend the complexity of the PC election and asked them to rectify the situation. ${ }^{(18)}$ Without satisfying Party leaders, the Party head of Liaoning Province, Wang Min, was transferred to the post of deputy director of the NPC's Education, Culture, and Public Health Committee. After a second round of investigation by the Central Inspection Group during February and April 2016, a new Central Case Examination Group (Zhongyang zhuan'anzu 中央专案组) was formed to follow up the investigation of election fraud, and more than 100 PC delegates and Party cadres were interviewed. (19) In August, Wang Min was officially expelled from the Party, followed by an official document that charged him with criticising the Party Centre (wang yi zhongyang 妄议中央), lacking party discipline after knowing he could not fulfil his personal political aspirations, and showing negligence in the massive election fraud in the LPC. (20) Meanwhile, a number of key Party cadres were also expelled from the Party from June to August 2016, namely, the former deputy directors of the $12^{\text {th }}$ Standing Committee of the LPC, Wang Yang 王阳 and Zheng Yuchao 郑玉焯, and former Standing Committee member Su Hongzhang 苏宏章. They were reported to be associated with not only the scandal in the 2013 election of

9. Shih Chih-yu, Collective Democracy: Political and Legal Reform in China, Hong Kong, The Chinese University Press, 1999, p. 165.

10. Jean-Pierre Cabestan, "More Power to the People's Congresses? Parliaments and Parliamentarianism in the People's Republic of China," ASIEN, 2006, pp. 42-69.

11. Qin Qianhong, "Liaoning hu xuan an cuibi xuanju zhidu gaige" (The incident of Liaoning's election fraud urges reform on electoral system), Wechat Public Account of Qin Qianhong, 18 September 2016, http://chuansong.me/n/798235344651 (accessed on 23 December 2016).

12. Cai Dingjian, "Zhengzhi tizhi gaige de lishi yu xianzhuang" (The present and the past of the political institution reform), Yanhuang Chunqiu, No. 2, 2011.

13. Ming Xia, The People's Congresses and Governance in China, op. cit:; He Zunzhi, Zuowei yi zhong zhengfu xingshi de zhongguo renda zhidu, op. cit., pp. 125-128.

14. "Liaoning hui xuan an: shiwuqianli pubian cunzai" (The incident of Liaoning's election fraud: No precedent and yet common existence), Deutsche Welle, 14 September 2016, http://dw.com/p/1K1sx (accessed on 17 December 2016).

15. Qin Qianhong, "Liaoning hu xuan an cuibi xuanju zhidu gaige," art. cit.

16. "Liaoning hui xuan an da saochu" (A big clean-up on the case of Liaoning), Caixin, 11 October 2016, http://211.137.8.230:8580/ffyw/mtpl/570.html (accessed on 18 December 2016); Choi Chi-yuk, "Behind the NPC vote-buying scandal," art. cit.

17. Chen Ling and Barry Naughton, "A Dynamic China Model: The Co-evolution of Economics and Politics in China," Journal of Contemporary China, Vol. 26, No. 103, 2017, pp. 18-34.

18. "Liaoning hui xuan an da saochu," art. cit.

19. Ibid.

20. "Wang Min geren zhengzhi qiwang wei shixian hou dichu zhongyang" (Wang Min defying the Central after failing to realise his personal political aspirations), The Beijing News, 26 August 2016, http://www.bjnews.com.cn/inside/2016/08/26/414767.html (accessed 29 November 2016). 
the LPC delegates to the NPC, but also other election scandals that might have helped them to gain office in the provincial legislature. In September, the former secretary of the Standing Committee Party group, Li Feng 李峰, was dismissed from his position in the LPC for negligence in the election fraud, a treatment unlike the 453 LPC delegates who resigned at the same time. The former Party head of the Discipline Committee of Liaoning Province, Wang Junlian王俊莲, also received a warning despite her retirement, and appeared on television to repent her negligence in the LPC election fraud as part of the Central Committee's effort to showcase its achievements in fighting corruption. As of 6 January 2017, there were 955 people under investigation or receiving punishment. (21)

For Xi Jinping, the large-scale re-shuffle of Party cadres in Liaoning Province could serve as a strong warning to others who dare to put personal interests above party discipline in the run-up to the $19^{\text {th }}$ National Party Congress. Steve Tsang argues that the upcoming National Party Congress is crucial for Xi's strategic manoeuvring for political succession and his selection of trustworthy allies, especially after his anti-graft campaign displeased a number of factions in the Party. ${ }^{(22)}$ At the $6^{\text {th }}$ Plenum of the $18^{\text {th }}$ CCP National Party Congress in November 2016, Xi Jinping openly warned of "political conspiracies of working with ostensible obedience while forming cliques to pursue selfish interests" among senior Party cadres. (23) In light of his statement, it remains to be seen to what extent Xi Jinping as the "Party core" will be able to assert control over local Party cadres.

\section{Private entrepreneurs in the People's Congress system}

Following the gradual development of the private sector since the economic reforms, the CCP has a complex relationship with the rising number of private entrepreneurs. For example, since the 1990s, a number of CCP cadres and their families became "red capitalists" who owned private firms converted from state-owned enterprises. In 2001, Jiang Zemin proposed the theory of "Three Represents," which officially allowed private entrepreneurs to join the Party. Scholars argue that this move was an attempt to justify the previously informal existence of "red capitalists" and to pre-emptively diffuse their potential to become an organised force against the CCP. (24) Moreover, it has been long observed that Party cadres and private entrepreneurs have developed intricate webs of guanxi for mutual benefit, (25) manifested in various informal patronage alliances crosscutting the line between the public and private sectors. ${ }^{(26)}$ Their collusion, however, often involves illegal activities such as corruption and embezzlement of state assets. (27)

Private entrepreneurs have also been granted representation in the NPC and National People's Political Consultative Conference (NPPCC) since the 1990s. According to calculations by Southern Weekly in 2010, about $9 \%$ of the delegates in the $11^{\text {th }}$ NPC (2008-2013) were owners of private enterprises. ${ }^{(28)}$ According to the Shanghai-based Hurun Research Institute, about $15 \%$ of private entrepreneurs on the China's Rich List were members of either the NPC or NPPCC from 2010 to 2013 , and as much as $30-40 \%$ of the 50 richest private entrepreneurs in China were also NPC/NPPCC delegates from 2010 to 2014. ${ }^{(29)}$

The reasons for private entrepreneurs to pursue a formal title in the PC system could be manifold. Chen Youxi argues that while local private entrepreneurs looked for informal political patronage from local Party secretaries for rent-seeking and political protection, the benefit obtained from guanxi is not solid because private entrepreneurs face the risk of policy reversal when new Party secretaries assume office. ${ }^{(30)}$ In the absence of de facto legal protection of private property, their business interests in a locality could also be susceptible to abuse of power by local Party cadres through the judiciary or simply through coercive force. ${ }^{(31)}$ Jiang Mingan observes that private entrepreneurs might also use their privileges as PC delegates to meddle in court cases related to them, given the constitutional right of the PC to oversee the judiciary at the same level. ${ }^{(32)}$ All these point to the advantages of holding a PC office in the formal political system besides the cultivation of guanxi.

Some observers also note that the specific economic structure of Liaoning Province could be one of the reasons for private entrepreneurs to aspire to PC positions that protect their business interests. As Liaoning's economy comprises predominantly state-owned enterprises in heavy industries with a relatively underdeveloped private sector, most resources are in the hands of government officials, rendering political connections a necessity for private entrepreneurs in the province. ${ }^{(33)}$ The formal position of PC delegate not only gives private entrepreneurs a greater sense of security for their business interests, but also allows more guanxi to be nurtured with government officials.

21. "Jiwei fanfu pian jie Liaoning hui xuan cha 955 ren" (Discipline Committee revealed 955 under investigation for Liaoning's election fraud), Hong Kong 01, 6 January 2017, http://www.hk01.com/article/64181 (accessed on 8 January 2017).

22. "China's President Xi Jinping faces his biggest political test," South China Morning Post, 21 October 2016, http://www.scmp.com/news/china/policies-politics/article/2022936/chinese-presidentxi-jinping-faces-his-biggest (accessed on 5 January 2017).

23. "China's Xi lashes out at political cliques, election fraud," Xinhua, 2 November 2016, http://news.xinhuanet.com/english/2016-11/02/c_135801155.htm (accessed on 5 January 2017).

24. Bruce J. Dickson, "Integrating wealth and power in China: The Communist Party's embrace of the private sector," The China Quarterly, Vol. 192, 2007, pp. 827-854; Kellee S. Tsai, "Adaptive informal institutions and endogenous institutional change in China," World Politics, Vol. 59, No. 1, 2006, pp.116-141.

25. Kellee S. Tsai, ibid:; Lü Qingchun, "Fei gongyouzhi jingji renshi de zhengzhi canyu jiqi kunjing" (The political participation and challenges of members of the non-public economic sector), Contemporary World and Socialism, Vol. 27, No. 1, 2009.

26. Bruce Dickson and Minxin Pei, "Red capitalists in China: Will entrepreneurs change the Party?", Carnegie Endowment for International Peace, 5 March 2003, http://carnegieendowment.org/ 2003/03/05/red-capitalists-in-china-will-entrepreneurs-change-party-event-593 (accessed on 19 January 2017).

27. The report on private entrepreneurs' crimes in China 2012, cited in Zhu Cheng, "minying qiye xuyao zenyang de falü baohu?" (What legal protection do private enterprises need?), South Review, 25 March 2013, http://www.nfcmag.com/article/3971.html (accessed on 5 January 2017); Minxin Pei, "Xi's war on corruption could hasten Chinese Communist Party's fall," Nikkei Asian Review, 4 June 2015, http://asia.nikkei.com/magazine/20150604-Cast-away/Viewpoints/MinxinPei-Xi-s-war-on-corruption-could-hasten-Chinese-Communist-Party-s-fall (accessed on 20 January 2017).

28. "Quanguo renda shou ti jiang ganbu daibiao bili" (The first time to mention the reduction of quota for Party cadre representatives in the National People's Congress), The Beijing News, 9 March 2012, http://www.chinaelections.org/article/26/224405.html (accessed 5 January 2017).

29. It should be noted that the criteria for the list compilation has been changed for 2009-2016. Private entrepreneurs will be put on the China Rich List when the assets they own meet certain criteria, such as being the 1,000 richest (2009-2013) and passing the threshold of 2 billion RMB (2014-2016). (Hurun Research Institute, The Hurun Report 2016, http://www.hurun.net/CN/ArticleShow.aspx?nid=20867 (accessed on 5 January 2017).

30. Chen Youxi, "Zhongguo minying qiye de sifa fengxian" (The judicial risks of private enterprises in China), Zhongguo Gaige, Vol. 11, 2011.

31. Yuhua Wang, "Institutions and Bribery in an Authoritarian State," Studies in Comparative International Development, Vol. 49, 2014, pp. 217-241. Zheng Yongnian, "Zhongguoshi fanfu jian zhi hechu" (Areas to be pointed at for anticorruption in China), I-Feng, 5 July 2016, http://3g. ifeng.com/news/sharenews.f?aid=110818912\&mid (accessed on 18 December 2016).

32. "Jie Liaoning renda daibiao luanxiang" (Revealing the mess of People's Congress delegates in Liaoning), Caijin, 9 September 2016, http://news.sohu.com/20160909/n468091763.shtml (accessed on 17 December 2016).

33. Ba Zunyu, "Jianli dongbei xinxing zheng shang guanxi de shenceng duice sikao" (Thoughts on the deep solutions to the construction of new party-business relation in Northeast), 12 November 2016, http://blog.sina.com.cn/s/blog_48350edc0102wi7j.html (accessed on 5 January 2017). 
In addition, scholars argue that private entrepreneurs are more eager than before to make political connections with government officials at the national level, as it helps them to obtain resources beyond their localities as well as more stable political protection from the central government. ${ }^{(34)}$ In the case of Liaoning's election fraud, the profiles of some disqualified NPC delegates suggest that they have business interests beyond the Northeast region. ${ }^{(35)}$ Also, specific to the Northeast region, the central government launched a strategic economic revival programme (Zhenxing dongbei 振兴 东北) in 2004 to rescue the declining economy there. However, many revival measures have not been properly implemented by the local government in Liaoning Province. (36) Business tycoons from Liaoning Province might want to gain the post of NPC delegate in order to have more direct access to national government officials and thus resources. The incentives and the financial capacity of Business tycoons to buy NPC positions, coupled with provincial cadres' insubordination to the Centre's orders for personal benefit in the opaque electoral process of the PC system, constitute the background of the incident of Liaoning's election fraud.

\section{New formulation of the Party-business relationship}

In order to harness the growing role of the private sector in economic development and to rid the process of corrupt behaviour, Xi Jinping in March 2016 urged Party cadres to cooperate closely with private enterprise (qin 亲) but also to be clean of corruption ( qing 清), forging what Xi called "the new Party-business relationship" (Xinxing zhengshang guanxi 新型政商关 系). He asked Party cadres to help private entrepreneurs without a mind for corruption or personal gain, and for private entrepreneurs to better communicate with Party cadres and operate businesses in a legal manner. ${ }^{(37)}$ Some related measures are observed. First, the Xi Administration issued guidelines (Zhonggong zhongyang guowuyuan guanyu wanshan chanquan baohu zhidu yifa baohu chanquan de yijian 中共中央国务院关于完善产权 保护制度依法保护产权的意见) in November 2016 that include ten specific measures to offer private entrepreneurs greater legal protection of their private property. Hu Shuli also points out that the guidelines show a more tolerant attitude towards assets of private entrepreneurs who accumulated their wealth illegally in the early days of economic reform, a major concern among private entrepreneurs. ${ }^{\left({ }^{38}\right)}$ As noted by Minxin Pei, many business tycoons actually acquired their wealth through corrupt guanxi with government officials or by cooperating with the latter to loot the assets of state-owned enterprises in the 1990s. ${ }^{(39)}$ Despite the effort to build up a stronger legal framework for the protection of private property, potential resistance by local governments to redress private-property cases in court could cast doubt on the effectiveness of the guidelines, ${ }^{(40)}$ and long-standing guanxi between local Party cadres who are accustomed to bribery and private entrepreneurs who have rent-seeking impulses might also discredit the usefulness of the legal framework in achieving the new Party-business relationship Xi envisions.

Moreover, the CCP continues to be in close contact with private entrepreneurs through its united front work as a means of control and feedback collection. In 2015, the CCP promulgated a new regulation (Zhongguo Gongchandang tongyizhanxian gongzuo tiaoli (shixing) 中国共产党统一战 线工作条例（试行）), which outlined two business-related categories of the 12 united front work targets for internal reference. ${ }^{(41)}$ While the co-optation of the super-rich into the NPC remains an objective of united front work under the Xi Administration, subtle changes have occurred in their representation in the NPC. Since 2013, representation quotas have been increased for some traditional sectors such as women, peasants, and workers. ${ }^{(42)}$ Concurrently, there has been a decline in the proportion of private entrepreneurs with the title of NPC delegate on the expanding China Rich List, which dropped from $8.2 \%$ in 2013 to $4.8 \%$ in 2016 . This shows that the CCP's co-optation strategy by way of NPC membership has not matched the rapid rise of the newly rich in China. ${ }^{(43)}$ Put together, they suggest that Party leaders may not want to see the NPC as an arena in which wealthy private entrepreneurs are co-opted as much as before, and certainly cannot tolerate private entrepreneurs who bribe their way into positions in the formal political system against the strategic planning of Party leaders, as in the case of Liaoning's election fraud.

\section{Concluding remarks}

The incident of Liaoning's election fraud in 2013 shows us how provincial Party cadres exhibited insubordination to their Party leaders in an electoral arrangement, resulting in the seizure of NPC positions by private entrepreneurs not pre-approved by Party leaders. The open sacking of senior Party cadres in Liaoning Province through informal party rules as well as the massive disqualification of LPC delegates by formal legislative procedures ought to be considered remedial measures by the central Party leaders to strengthen political control over Liaoning Province in the context of the anti-graft campaign and intense intra-party factional struggle. The disqualification of 45 NPC delegates from Liaoning Province, of which private entrepreneurs comprise a majority, does not signal a termination of the symbiotic relationship between the CCP and business tycoons, but re-affirms the Party's leadership as paramount in the Party-business relationship. Under the Xi Administration, it is noticeable that Party leaders are willing to keep the super-rich in the PC system as allies in economic development. Yet, the protection of their interests is perhaps not granted predominantly through the expansion of formal political positions in the NPC on par with their rapid rise in number, but more so through the informal channels of united front work and promised legal protection of their property rights in

34. Yuhua Wang, "Beyond Local Protectionism: China's State-Business Relations in the Last Two Decades," China Quarterly, Vol. 226, pp. 319-341, 2016; Lynette H. Ong, "Between Developmental and Clientelist States: Local State-Business Relationships in China," Comparative Politics, Vol. 44, No. 2, 2012, pp. 191-209.

35. For example, seven of the 45 disqualified delegates have assets over 2 billion RMB and appeared on the China Rich List (Hurun Research Institute, The Hurun Report 2016, art. cit.).

36. Ba Zunyu, "Jianli dongbei xinxing zheng shang guanxi de shenceng duice sikao," art. cit.

37. Li Jinhe and Gao Guosheng, "Goujian qin he qing de xinxing zhengshang guanxi" (Constructing "close" and "clean" Party-business relationship), Hongqi Wengao, Vol. 22, 2016.

38. Hu Shuli, "Strong property rights for a stronger Chinese economy," East Asia Forum, 9 January 2017, http://www.eastasiaforum.org/2017/01/09/strong-property-rights-for-a-stronger-chineseeconomy/ (accessed on 18 January 2017).

39. Minxin Pei, "Xi's war on corruption could hasten Chinese Communist Party's fall," art. cit.

40. Zhang Wenkui, "Chanquan baohu: xu yao wenjian geng xuyao pan li" (property right protection: document is required but actual court verdict more important), Caixin, 30 November 2016, http://opinion.caixin.com/2016-11-30/101020782.html (accessed on 6 January 2017).

41. "Zhonggong zhongyang yinfa zhongguogongchandang tongyizhanxian gongzuo tiaoli (shixing)" (The Central Committee of the CCP promulgated "(Temporary) Regulation on United Front Work of the Chinese Communist Party"), Xinhua, 22 September 2015, http://news.xinhuanet.com/politics/2015-09/22/c_1116645297.htm (accessed on 5 January 2017).

42. "Shierjie quanguorenda daibiao goucheng tese fenxi" (Analysis of the features of the composition of the 12th National People's Congress), Xinhua, 1 March 2016, http://news.xinhuanet.com/ 2013/h/2013-03/01/c_124404601.htm (accessed on 18 January 2017).

43. Hurun Research Institute, Hurun Report 2016, art. cit. 
return for their continued loyalty to the Party amidst economic downturn and a re-shuffling of their political allies within the Party. The unprecedented action by the NPCSC to eradicate election fraud in both the NPC and the LPC should not be mistaken for refining the quality of elections in a more democratic direction, nor should this move be regarded as propelled by the fear of Party leaders that private entrepreneurs pose a real threat to the CCP's monopoly of power, as it is highly unlikely that private entrepreneurs could or would organise to oppose the CCP as a unified group. ${ }^{(44)}$ Rather, it is more like an attempted "revolution from above" (45) to ensure the dominance of the CCP over wealthy private entrepreneurs and the supremacy of the Secretary General over the Party in both the formal and informal politics of the socialist political system.

Inthony H. F. Li is a research assistant at CEFC

(anthonylihf@gmail.com).

CEFC News Analysis is compiled from the CEFC's fortnightly selection of Press Highlights, available at www.cef.com.hk. 